\title{
USING REMOTE SENSING FOR LINEAMENT EXTRACTION IN AI MAGHRABAH AREA - HAJJAH, YEMEN
}

\author{
F. Al-Nahmi ${ }^{\text {a* }}$, O. B.Alami ${ }^{\text {b }}$ L. Baidder ${ }^{\mathrm{a}}$, K. Khanbaric ${ }^{\mathrm{c}}$, H. Rhinane ${ }^{\mathrm{a}}$, A. Hilali ${ }^{\mathrm{a}}$ \\ ${ }^{\text {a }}$ Laboratory Geosciences, Department of Geology, Faculty of Sciences, Hassan II University Casablanca, Morocco \\ ${ }^{b}$ Hassania School of Public Works, Morocco \\ (geofuad, alami.ehtp, lbaidder, h.rhinane)@gmail.com, a.hilali@fsac.ac.ma \\ 'Yemen Remote Sensing and GIS Centre, Sana'a University, Yemen - kkhanbari@ hotmail.com
}

KEY WORDS: Remote sensing, lineament extraction, Landsat 8_OLI, MNF, PCA, Yemen.

\begin{abstract}
:
Remote sensing and GIS data have become more and more important for the study of geology, structural geology and extract of lineament which give us an overview of the tectonic events. The main objective of our study is to design a method for extracting and mapping of lineament from Landsat 8_OLI satellite images of the study area. Different processing techniques were used to achieve our objective : MNF Minimum Noise Fraction bands $(4,5,6)$, Color composites $(7,5,3)$, PCA Principal Component Analysis bands (4,5,7), band ratios (7/5,6/4,4/2), directional filters, and image processing applied on the Landsat 8_OLI composite colours. The results of this study indicate that, the area is really affected by several structural trends: N-S, NW-SE, and NE-SW directions. The result of lineament analysis gives us a good interpretation of the main structural
\end{abstract} geology and tectonic forces.

\section{INTRODUCTION}

The application of remote sensing technology cover many fields of studies, such as structural geology, and mineral exploration, it is also useful for lineament and structure features extractions. (Anwar Abdullah et al. 2013). Lineaments are natural, linear surface elements, interpreted directly from satellite imagery and geophysical map which have been called fracture traces, and many other names (Parizek 1976; Garza and Slade 1986; O’leary et al. 1976). The remote sensing used also for water resource investigations (Boyer and McQueen 1964; Brown 1994; Lattman and Parizek 1964; Peterson 1980; Mah et al 1995; Dhakate et al. 2007) and structural geologic studies (Blanchet 1957; Henderson 1960; Lattman and Segovia 1961; Caran et al. 1982; Acharya et al. 2007). Using digital image enhancements including data processing (PCA, MNF, ICA), then band rationing colour composites (true or false), next improvements to the edge, image fusion, and the reduction of missed data (PCA, ICA), the spectral index has facilitated the differentiation and characterization, various structural elements of the geology, mineralization and Applied Studies of soil (Chen and Campagna, 2009; Gupta, 2013; Prost, 2001). According to this paper different processing techniques were used to achieve our objective, MNF Minimum Noise Fraction, Color composites, PCA Principal Component Analysis, band ratios, directional filters, and image processing applied on the Landsat 8_OLI composite colours for extraction of lineaments.

\section{GEOLOGICAL SETTING}

The Precambrian basement rocks of the area study comprise a succession of metamorphosed volcanic and volcanosedimentary rocks produced in an arc environment. These rocks are intruded by gabbro, syn- tectonic, post-tectonic granite and granodiorites. The Precambrian basement rocks represent the southwest extension of Nabitah belt, which is a part of the Arabian shield. They are unconformably overlain by sedimentary rocks Akbra Shale, Kohlan Sandstone and Amran limestone. A number of tectonic events had affected these rocks. The first effect is associated with the movement of the Arabian plate away from the African plate in a NE direction since $40 \mathrm{Ma}$. (Beydoun, Z.R., 1970). The two young ocean basins Red Sea and Gulf of Aden come as a result of this effect. The second effect is associated the intrusion of post tectonic granites and granodiorites, (fig.1).

\section{STUDY AREA LOCATION}

The study area is located between longitudes $\mathrm{E} 43^{\circ} 30^{\prime}-43^{\circ} 45^{\prime}$ and latitudes $\mathrm{N} 15^{\circ} 45^{\prime}-16^{\circ} 00^{\prime}$.in the southeast of Hajjah governorate, north west of Yemen, the relief of the area is mountainous with moderate to sleep slopes and sharp ridges. The study area access by car, 150 $\mathrm{km}$ from Sana'a. The sea level about 900-1500 meter (fig.2); this area has a good potential of mineral exploration in gold deposits, many companies work there and get a good result.

* Corresponding author 


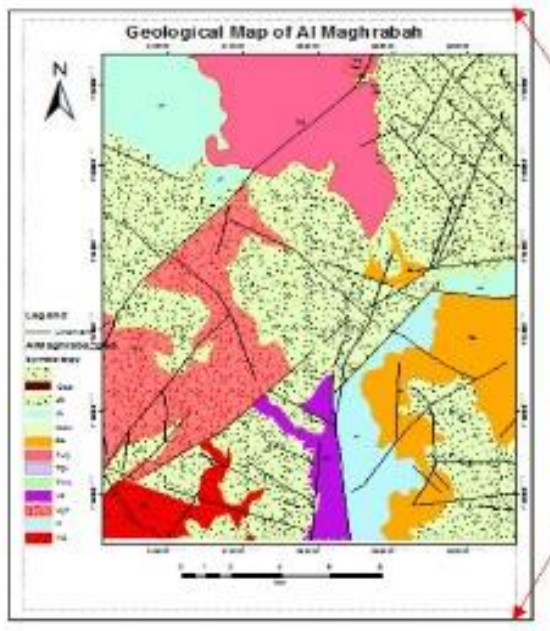

Figure 1. Geological map of the study area

\section{METHODOLOGY AND MATERIALS}

Many techniques have been developed to identify the linear features and the geomorphological characteristics of the terrain. Landsat bands are known for particular applications: band 7 (geology band), band 5 (soil and rock discrimination) and band 3 (discrimination of soil from vegetation) (Boettinger et al., 2008; Campbell, 2002, 2009; Chen and Campagna, 2009). Band ratios are also known for eliminating shadowing and topographic effects which is suitable for complex terrain.

\subsection{Data description and image enhancements}

Satellite image Landsat 8, (OLI, year 2014), scenes LC81660492014196LGN00 free downloaded from the USGS web site page and pre-processed to reduce the effects of haze before mosaicking and sub setting. The following image enhancement techniques were applied to Landsat imagery: PCA, ICA, MNF Band rationing, RGB band combinations, difference stretch, and RGB combinations having the highest contrast. Most contrast on lithological features on Landsat 8, RGB bands $(7,5,3)$ were enhanced further using difference stretch and IHS transformation. PCA was using all Landsat bands to determine the lineaments easily .PCA containing the most information from bands (1, 5, 6), (fig.3), MNF most formations coming from bands $(7,5,1)$, (fig.4) and ICA from bands (1, 5, 7),(fig.5). Were found to enhance lithological features and were compared to band ratio combinations band $(7 / 5,6 / 4,4 / 2)$ to extract easily the lineament.

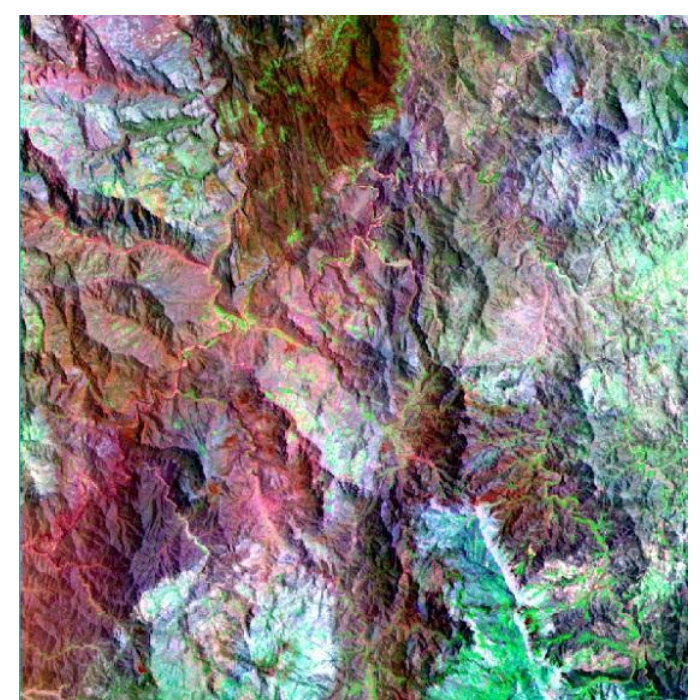

Figure 3. PCA band $(1,5,6)$ Combination

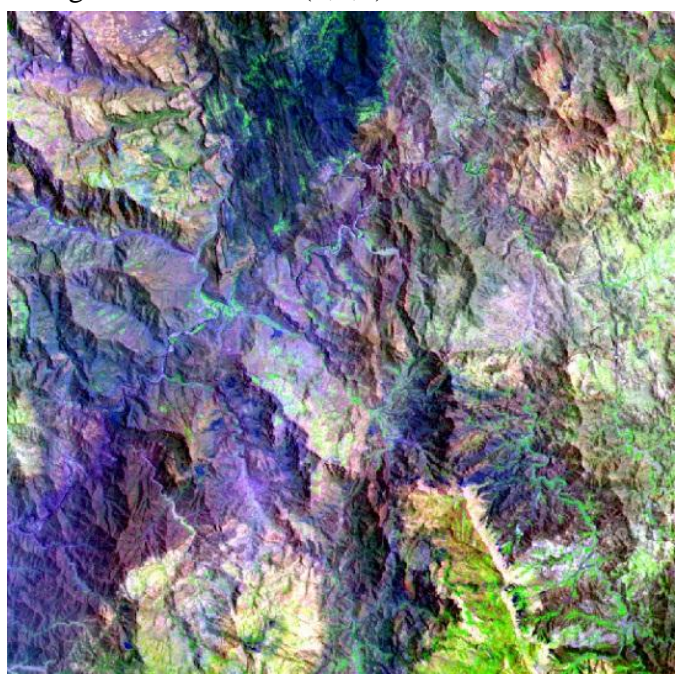

Fig.4. MNF band $(7,5,1)$ Combination 


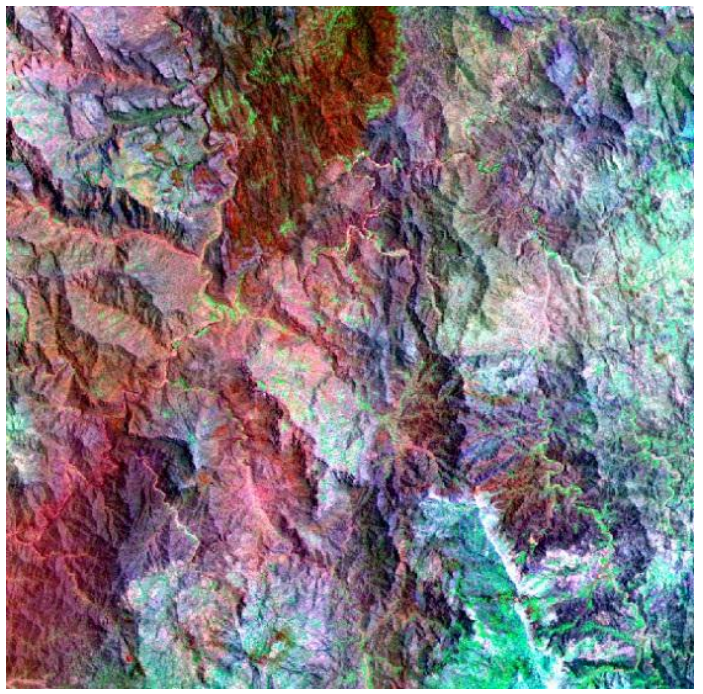

Fig 5. ICA band $(1,5,7)$ Combination

\subsection{Lineament extraction}

\subsubsection{Manual lineament extraction from geological Map:}

This method depends on extract lineament via digitizing the lineament from the geological map of Maghrabah a scale 1: 250.000.from this method we get 49 lines from the map geology. (Fig. 7).

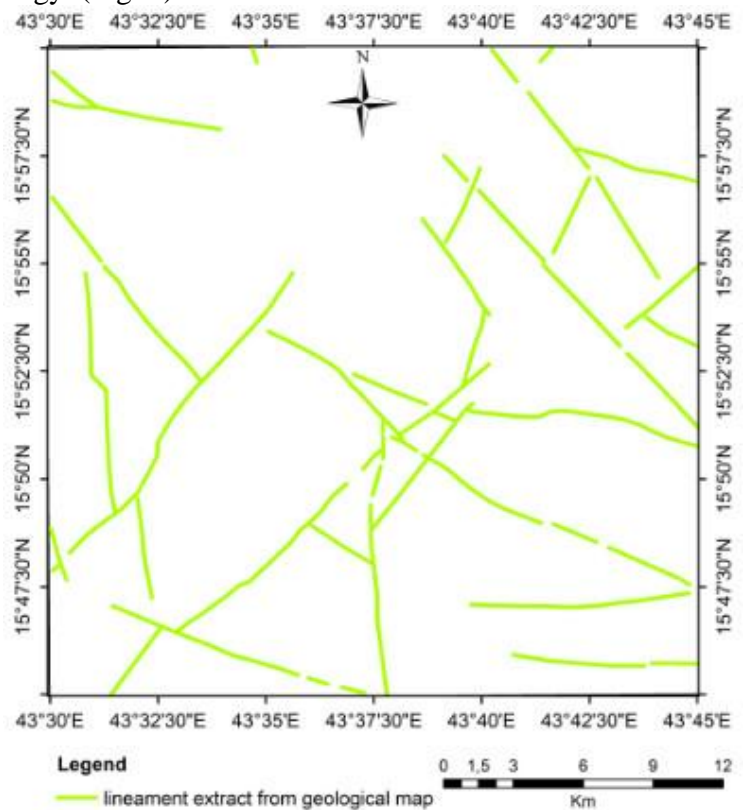

Figure 7. Lineament extraction from geological map

\subsubsection{Manual lineament extraction from satellite images processing:}

This method depends on extract lineament via digitizing the lineament from the Satellite image of Maghrabah area, the processing of Landsat 8_OLI for visible lineaments and faults in composite image satellite image, PCA colour composite bands $(1,5,6)$, ICA colour composite bands $(1,5,7)$, and

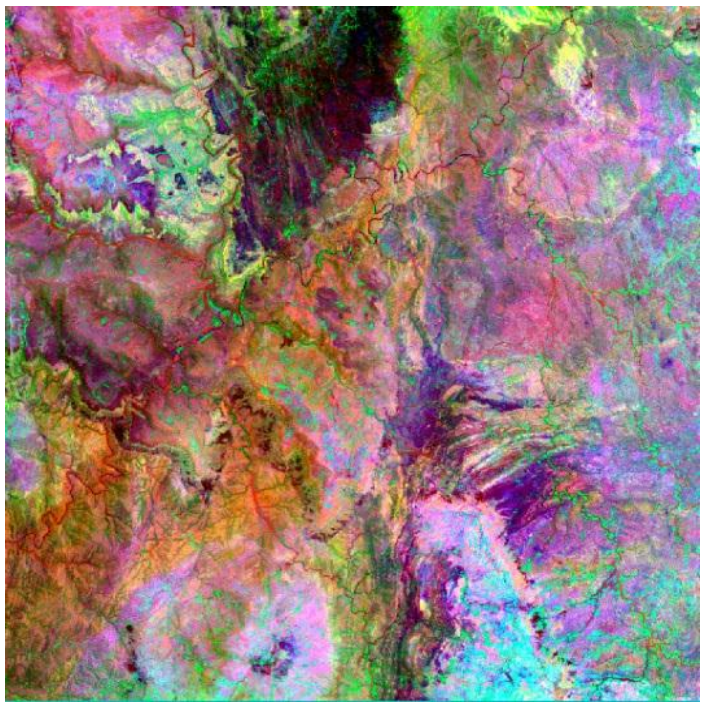

Fig 6. Band Ratio (7/5, 6/4, 4/2) Combination

MNF colour composite bands $(7,5,1)$. These were used as a reference for the manual extracted lineament. Band ratios $(7 / 5$, $6 / 4,4 / 2$ ) it's suitable for distinguished clearly between the rocks unites. Landsat 8 OLI satellite data were used band 1 to 7 likes layer stacking and resolution merge it with band 8 was found as the most suitable method for distinguishing various lithology classes and easy to extraction the lineament, from this method we get 172 lines comparing with another method we get only 49 line from the geological map.

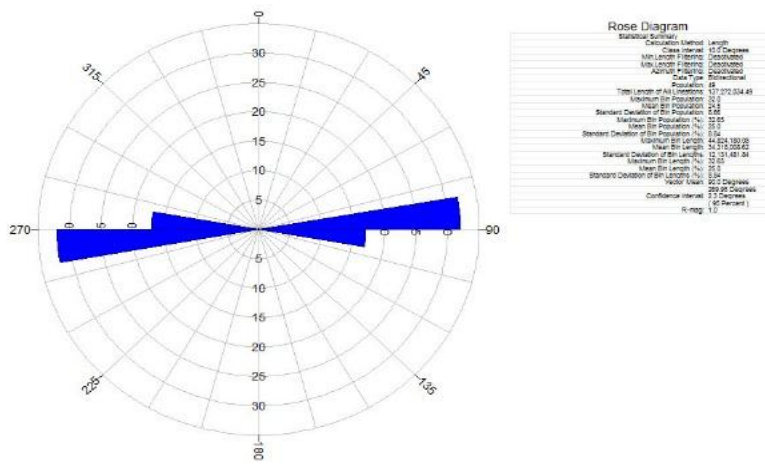

Figure 8. Rose diagram of lineament extraction from geological map

\section{RESULTS AND DISCUSSIONS}

In general combinations involving bands from each spectral region (i.e. visible, mid infrared and SWIR II) were found to have more contrast on lithological features, Landsat 8_OLI, RGB bands 7,5,3 were enhanced further using difference stretch and resolution merge was formed using all Landsat bands and Factor loading done to determine the RGB containing the most information from bands $(7,5,3)$. Were found to enhance lithological features and were compared to band ratio 
combinations (7/5,6/4,4/2),(fig.7)principal components analysis, PCA $(1,5,6)$, minimum noise feature $\operatorname{MNF}(7,5,1)$ and independent component analysis, ICA $(1,5,7)$ for getting easy method to extract the lineaments. A slight variation of the same was achieved using an FCC comprising: ICA ,PCA ,MNF and Band ratios with the most geological information as the Red and green channels while the blue channel was the saturation band the IHS transform of RGB combinations for bands $(7,5,3)$ .Laake, (2011) using Landsat multi-band RGB 742, distinguished clearly between the basement rocks, the Mesozoic clastic sedimentary rocks and coastal carbonates, while the difference between bands 4 and 2 highlighted difference in lithology between pure limestone and more sand cover. The result of lineament analysis gives us a good interpretation of the main structural geology and tectonic forces, (fig.9), and tell us the area is really affected by several structural trends: N-S, NW-SE, and NE-SW directions. (fig.10).

\subsection{Analysis of lineaments}

The lineament extraction from geological map scale 1:250000 was 49 lines, on the other hand the lineament extraction from satellite images after processing and enhancement, (ICA, PCA, MNF, Band ratio) around 172 lines (Table.1).

\begin{tabular}{|lcl|}
\hline & Geological Map & Image Processing \\
\hline Count & 49 & 172 \\
\hline Minimum & 0.314506 & 0.00664 \\
\hline Maximum & 15.342449 & 27.038744 \\
\hline Sum & 206.588995 & 543.819434 \\
\hline Mean & 4.216102 & 3.161741 \\
\hline Standard Deviation & 3.1438 & 3.08555 \\
\hline
\end{tabular}

Table 1. Comparisons between the lineament extraction from geological map and from the image processing.

\subsection{Density analysis}

Lineament that extract from the geological map give us the total direction of the lineaments in the E-W, (fig.8) and this is not the same direction of the geological setting that means this lineaments are inaccurate to explain the geological structures of the area. In other hand our process for Landsat 8_OLI and enhanced by multi-processes such as (PCA, ICA, MNF) is greatly affected by several structural trends: N-S, NW-SE, and NE-SW directions. And it is better for interpretation of the geological setting of the study area (fig.10).

\subsection{Validation}

For validation our study, we have superposition the lineament that extract from satellite image with the geological map. The results are compatible with the geological situation of the study area, according to a report of the Geological survey and mineral resources board of Yemen, the geological map and field visits to the area, (fig.11).

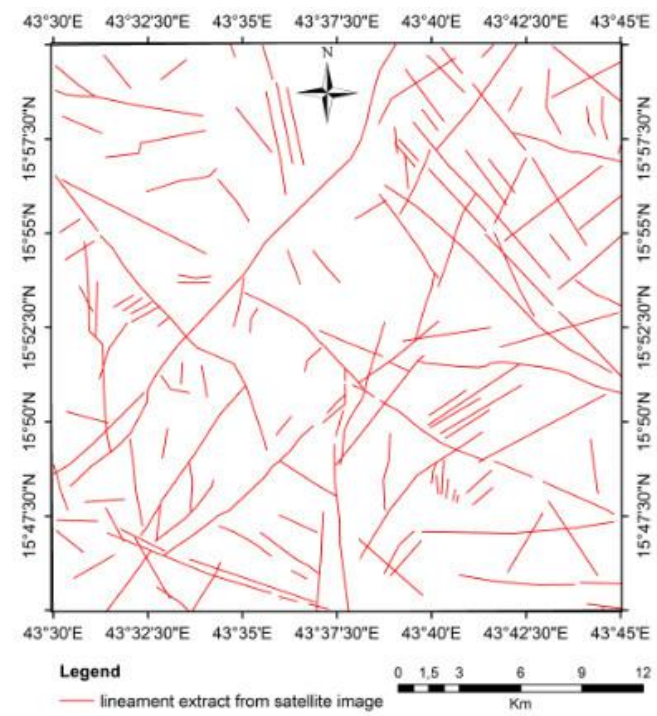

Figure 9. Final map of Lineament extraction from satellite image
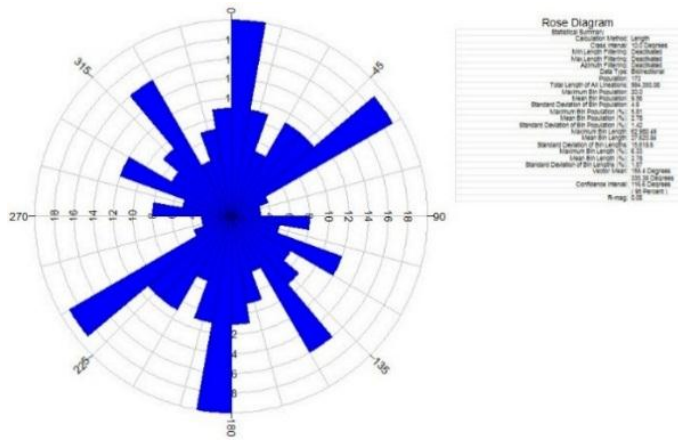

Figure 10. Rose diagram of lineament extract from satellite image.

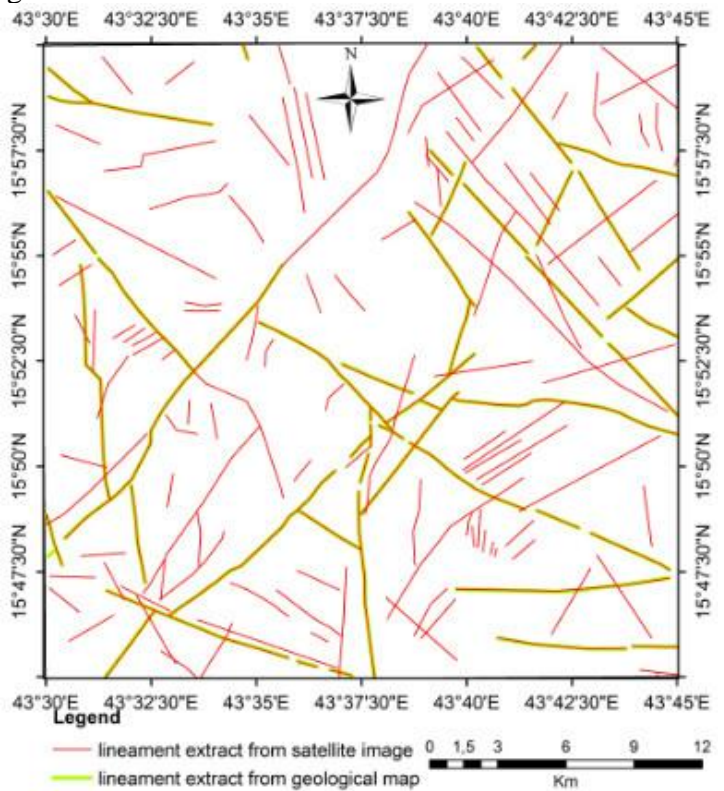

Figure 11. Superposition the lineament extraction from satellite image with geological map of the study area. 


\section{CONCLUSIONS}

The satellite image Landsat 8_OLI has higher spatial resolution SWIR $(30 \mathrm{~m})$ bands 1 to 7 and $(15 \mathrm{~m})$ for band 8 . Resolution marge providing us a powerful for lineament study and analysis, especially in the study area. The image enhancement was one of the useful tools to improve the interpretability or perception of information in images for human viewers, or to provide better input for automated image processing techniques, one of those enhancements is an edge sharpening enhancement technique for enhancing the edges in an image. PCA, ICA, MNF processing makes the viewer of the lineament very clear and easy to extract the lineaments and distinguished between the lithology units. The use of RGB combination involving an ICA, PCA and saturation band of the RGB bands contributing most to enhancing geology, was explored as an image enhancement technique and it has better visualization of lineaments compared to RGB combinations. The extraction of lineaments depended on the ability to enhance texture which was better in band ratios $(7 / 5,6 / 4,4 / 2)$, PCA $(1,5,6), \operatorname{MNF}(7,5,1)$, ICA $(1,5,7)$ for Landsat 8_OLI. As a result of the lineament analysis, which give us a good explanation for the main structural geology and tectonic events and tell us the area really affected by several structural trends: NS, NW-SE, and trends NE-SW, which is consistent with the geological reports for the area, on the other hand the lineament indicate that the area affected by the same geological events which affected the Arabian shield.

\section{ACKNOWLEDGEMENTS}

We would like to thank all of our reviewers who have worked to improve the quality of this paper. We also thank the YCRS (Yemen Centre of Remote Sensing) / YGSMB (Yemeni geological survey and mineral resources Board) cooperation for their continued support in this research study.

\section{REFERENCES}

Acharya T, Basumallik S and Paul S K 2007 Comparative analysis of lineaments and fractures in Precambrian crystalline rocks using remote sensing and field technique: A case study in and around Balarampur, Purulia District, West Bengal, India; Abstract, Proc. International Conference on Precambrian Sedimentation and Tectonics and Second GPSS Meeting, 10-12 December 2007, IIT Bombay, Mumbai, pp. 68-69.13.

Anwar Abdullah et al. Landsat ETM-7 for Lineament Mapping using Automatic Extraction Technique in the SW part of Taiz area, Yemen, Global Journals Inc.(USA) Volume 13 Issue 3 Version 1.0 Year 2013.

Beydoun, Z.R., 1970. Southern Arabia and northern Somalia: Comparative geology. Philosophical Transactions of the Royal Society of London Series A, Mathematical and Physical Sciences, 267 (1181): 267 -292.

Blanchet P H 1957 Development of fracture analysis as an exploration method; Am. Assoc. Pet. Geol. Bull. 40 1748-1759.
Boettinger, J.L., Ramsey, R.D., Bodily, J.M., Cole, N.J., Kienast-Brown, S., Nield, S.J., Saunders, A.M., and Stum, A.K. (2008). Landsat Spectral Data for Digital Soil Mapping. In Digital Soil Mapping with Limited Data, A.E.

Boyer R and Mcqueen J 1964 Comparison of mapped rock fractures and airphoto linear features; Photogram. Eng. Remote Sens. 30 630-635.

Campbell, J.B. (2002). Band ratios. In Introduction to Remote Sensing, (New York: Guilford Press), p. 505.

Caran C S, Woodruff C M Jr and Thompson E J 1982 Lineament analysis and inference of geologic structures examples from the Balcones/Ouachita trend of Texas; University of Texas at Austin, Bureau of Economic Geology, Geological Circular 82(1) 59-69.

Chen, X., and Campagna, D.J. (2009). Remote Sensing of Geology. In The Sage Handbook of Remote Sensing, (Thousand Oaks, CA: Sage), pp. 328-340.

Dhakate R, Singh V S, Negi B C, Chandra S and Rao V A 2007 Geomorphological and geophysical approach for locating favorable groundwater zones in granitic terrain, Andhra Pradesh, India; J. Environ. Manag., doi: 10.1016/j.jenvman.2007.07.014.

Gupta, R.P. (2013). Remote Sensing Geology (Berlin, Heidelberg: Springer Berlin Heidelberg).

Hartemink, A. Mcbratney, and M. De L. Mendonça-Santos, eds. (Dordrecht: Springer Netherlands), pp. 193-202.

Henderson G 1960 Airphoto lineaments in Mpanda area, Western Province, Tanganyika, Africa; Am. Assoc. Pet. Geol. Bull. 44 53-71.

Laake, A. (2011). Integration of satellite Imagery, Geology and geophysical Data. In Earth and Environmental Sciences, (INTECH Open Access Publisher), pp. 467-492.

Lattman L H and Parizek R R 1964 Relationship between fracture traces and the occurrence of groundwater in carbonate rocks; J. Hydrol. 2 73-91.

Lattman L H and Segovia A V 1961 Analysis of fracture trace pattern of Adak and Kagalaska Islands, Alaska; Am. Assoc. Pet. Geol. Bull. 45 249-251.

Mah A, Taylor G R, Lennox P and Balia L 1995 Lineament analysis of Landsat Thematic Mapper Images, Northern Territory, Australia; Photogram. Eng.Remote Sens. 61 761773.

M. W. Mwaniki, M. S. Moeller, and. Schellmann. A comparison of Landsat 8 (OLI) and Landsat 7 (ETM+) in mapping geology and visualising lineaments: A case study of central region Kenya. The International Archives of the Photogrammetry, Remote Sensing and Spatial Information Sciences, Volume XL-7/W3, 2015 pp.897-903. 
O'leary D W, Freidman J D and Pohn H A 1976 Lineament, linear, lineation: Some proposed new definitions for old terms; Geol. Soc. Am. Bull. 87 1463-1469.

Prost, L.G. (2001). Remote sensing for geologists: a guide to image interpretation ([Amsterdam]; New York; Abingdon: Gordon \& Breach ; Marston).

Tapas Acharya1, and Sukumar Basu Mallik Analysis of lineament swarms in a Precambrian metamorphic rock in India J. Earth Syst. Sci. 121, No. 2, April 2012, pp. 453-462

Umikaltuma Ibrahim Felix mutualineament Extraction Using Landsat 8 (OLI), in Gedo, Somalia. International Journal of Science and Research (IJSR) Volume 3 Issue 9, September 2014 pp. $291-296$.

Yemen Geological Survey and Mineral Resources Board (UGSM), 1990. Geological map of Sana'a, $1^{\text {st }}$ edition, $1: 250.000$ 